\title{
Ecology, Stakeholder Management and Corporate Social Responsibility
}

\author{
María Isabel Huerta Viesca \\ University of Oviedo, Asturias, Spain
}

\begin{abstract}
This paper proposes a reflection on the appropriateness of the introduction of a new legal front in favour of maximum prevention by the managers of the companies potentially being responsible for environmental damage.

Keywords: prevention, environmental damage, managers, companies, responsibility
\end{abstract}

\section{Purpose and Objectives: Maximum Legal Prevention of Environmental Damage}

The experience of these first years of the 21st century shows that national and international legal norms have not been able to successfully prevent production accidents and damage to the environment with dire consequence for the natural environment (Bas, 2017). International environmental liability and Spanish legal systems are based on the principles of prevention and, above all, on the principle that "who pollutes, pays". Getting the repair of damages is the primary objective of all legal texts. However there is a thing to take into account that the cost of repairing ecological damage is economically very high. In many cases the repair is impossible if the damage has occurred. When an operator has created environmental damage, it will result in fling against pecuniary liability.

Spanish Law 26/2007, about environmental responsibility, defined "operator" as any physical or legal person, public or private, which plays an economic or professional activity, or checks such activity, or has decision over its technical functioning economic power (and with or without lucrative purpose). It is a very general concept, although in practice most often is that the pollutant subject is a social entrepreneur and in particular a capital company (shaped like a corporation or limited liability company). This operator will normally be a mercantile society, which will be bound to its dissolution, with the additional damage that this implies for all stakeholders (employees, suppliers, customers, etc.).

And even in cases in which the Administration pays - if the contaminant entity cannot pay-, the final cost of the repair has an impact on all citizens. That explains the insistence in the preventive mechanisms enabling.

This paper proposes a reflection on the appropriateness of the introduction of a new legal front in favour of maximum prevention by the managers of the companies potentially being responsible for environmental damage.

Ten years ago, as a result of the transposition of European Community legislation, the environmental liability law was passed in Spain. Original and innovative, as the Spanish legislator's own contribution, this law

María Isabel Huerta Viesca, accredited professor of Commercial Law, Department or Commercial Law, School of Law, University of Oviedo, Asturias, Spain.

Correspondence concerning this article should be addressed to María Isabel Huerta Viesca, Avenida del Cristo s.n., Oviedo, Asturias 33006, Spain. 
makes the managers of enterprises that have caused environmental damage in personal responsible for that damage. From this point of view that managers' social responsibility mechanism can be used as a very interesting and effective preventive formula prior to the causation of the environmental damage, and not just Spanish internally, because it entails a lift—very important—-the level of due diligence to administrators of companies that are, as a practical sample, the main agents of contamination.

And, from another perspective, we consider that this new responsibility can also help to increase the profits of the enterprise to improve its image, if it uses the conduct of the company within the framework of corporate social responsibility and not only within the framework of strict legality.

\section{Social Interest and Interests of Corporate Social Responsibility}

For a long time, it was considered unanimously that the interest of the society, the company, was the common interest of the partners. This interest was mainly translated into profit by members from the profits of the company. This concept, known as "contractual", closes the eyes to social reality external to the company, which becomes a wealth generator instrument directly to members. Only indirectly-through the enrichment of the partners and the greater movement of goods, or the increase of jobs in the company, which would be in the general well-being — benefits for the rest of civil society could be perceived.

From this perspective the company yields correspond to who has risked his capital in it and the interests of third parties are not deserving of special protection against the company. This theory seemed irrefutable in the case of the large corporation and extended also to the limited liability companies, small or family, due to the unitary sense of both social types in the corporate law world.

The definition of the concept of social interest was not never fully closed, however. Just think of the debate that has been causing in line with the reforms of the corporate laws during the 21st century in France, or the deep doctrinal discussion in Italy or Spain. Many issues intertwined with this concept are not clear to translate it into practice problematic. This is often the case with the challenge of "contrary to the social interest" social arrangements, or the difficulty of finding and defining the "common" interest of the partners.

In recent years step has opened a ground-breaking, entirely new conception of social interest, which departs from the exclusive "common interest of partners" and its particular benefit and moves away from the aforementioned contractual theory. It conceives social interest from a completely different perspective, which could be described as institutionalist theory. The social interest (the interest of corporate society) today will be the social interest, i.e. the interest of the company as a whole and as organism alive, responsible and active in civil society. From this new point of view, social interest includes business interest in a total whole, with the interests of minority shareholders, the interests of the workers, nor the interest of customers and suppliers, or even other more complex concrete and diffuse interests.

That international legal doctrine has very important consequences: mean present interests that until now had been relegated. Putting the spotlight on these new subjects "interested" in the company means to highlight aspects and interests which, although they could never be ignored entirely by its economic weight-as a load-to the company, were taken into account as guiding beacons on the progress of the companies nor were considered relevant at all to the social goal.

Just put the example of the attention to the interests of workers (Chulià, 1993), especially in large companies and multinationals, or the case of the social interest which should be object of protection when the company is at the gates of the insolvency (Marín De La Bárcena, 2004). In the last years of the second decade 
of the century the scope of social interest began to be held legally in various legal systems, it should be expanded further to other diffuse interests.

After an iter full of difficulties, various positive laws incorporated the protection of the dispersed interests of other subjects linked to societies but that are not necessarily partners. The perspective is changed again to analyse the objectives of the company, which now become much more than an instrument so that partners or some related society receive direct benefits (Buonocore, 2004).

Now it is the legislator who takes into account these new "social interests" from companies to regulate company law and it has practical implications of all draft. If the particular commercial legal rules collect-as thus is happening now, albeit timid way-those new interests at stake as part of the "social interests" of the companies, already may not act in exclusively a few specific shareholder interest, whether or not mainstream, but it must also act in the interest of those third parties subject, linked with the society and which do not coincide with the partners.

Who are these new individuals whose interests are worthy of protection to form the "social interest"? At the moment the list of interests at stake is not defined. Such subjects are, for example, the stakeholders (Caussain, 2004; Visconti, 2004) that is, customers, especially the consumers and users, workers, creditors, financial institutions, suppliers, public administration...and also civil society, future generations... and therefore always regard all those third-party relations with the mercantile society business (Baums \& Scott, 2003; Hopt \& Leyens, 2004). As well, within those interests to take into account as a guide for the company stand out increasingly clearer profiles and stronger environmental protection and reduction of the environmental impact of the activity of the company.

From the new laws that are the tenets of corporate social responsibility the company is conceived as a gear which has combined and operate harmoniously internally — to get his survival, that affects everyone - and also externally, to be an engine of wealth and direct growth for all the social and natural environment. The company, public or private, must respect other interests and ethical duties that go well beyond the strict economic interests of the company; among them are the interests of protection of the environment and ecology (Brudney, 1982; Crook, 2005; Bernaldo De Quirós, 2005).

A key milestone in this direction has been, in Europe, the adoption of Directive 2004/35/EC of the European Parliament and of the Council of 21 April 2004 on environmental liability with regard to the prevention and remedying of environmental damage, which should be transposed more by April 30, 2007.

Within the framework of corporate social responsibility, new forms of demand for responsibility have emerged when the company breaches its new goal—heritage obligations to the environment. We could frame these new responsibilities within the general framework of aggravation of demands by some ethical considered conduct, result of general social irritation — and we are referring to a global international level, not only local. In the environmental field this irritation is the result of phenomena such as desertification, global warming, floods, or melting of the Poles that affect all humanity and, in particular, in some way, all environments and species.

There is no doubt that the values which protect the corporate social responsibility, and especially the ecological and environmental liability, are welcomed mostly as very positive by the civil society, that it does not hesitate to criticize and evaluate corporate social responsibility expressed by the company and opted for or against it, buying products or using services, as their perception is. This entails the major risk of its conversion into a mere instrument of superficial marketing and makeup (Salvadores, 2004; Del Río, 2004), although it is 
also true that in many cases the effect of injury to the environment cannot hide in any way because new technologies allow knowing damage, sometimes devastating, taking place in real time (Orozco, 2015).

Another risk to consider is the quantification of the value that must be granted to these new interests worthy of guardianship and protection that must be respected for the company (at this time, respect for the environment and ecological values). Do these values have to be placed above all other values of the company? Let us not forget that we are talking about almost always capitalist companies, societies in which, as its name indicates, what matters are the capital contributing partners, usually shareholders, in order to obtain a benefit by participating in the gains made by the company.

And the conception of capitalist enterprise, therefore aimed at obtaining a profit, which is the engine that drives the creation and maintenance of these companies, has not changed at all. And let us not forget either that, as stated at the beginning, new values at stake-and among them, the responsibility for caring for the environment, or ecology - do not come to replace nor to novar to the old value of giving priority to the benefit of the partners, the creation of value for shareholders or shareholder value, but in addition to this value giving place to a plural arch of values that the company must address jointly in its performance, although without neglecting the most basic, consisting of own conservation and maintenance in running the business profitable (Miras Rodríguez, Carrasco Gallego, \& Escobar Pérez, 2014; Fernández García, 2016) and socially responsible.

This critical perspective shows the fragility of corporate social responsibility, which is still very young and must also be taken into account: note that we speak about legal values now-and in many cases legal but not imperative, of voluntary compliance by businesses - very recently. It's about youth rights, in the sense that they are rights underdeveloped yet, both in its roots and forms of protection by the legislators, who are usually very vague and "soft".

\section{The Environmental Responsibility of the Company}

Citizens have the right to enjoy an appropriate environment. In the Spanish Constitution of 1978, Spanish law incorporates this right in its article 45, within the framework of the "guiding principles of social and economic policy". At the highest level of European community we need to refer also to article 194 of the new Treaty on the functioning of the European Union, which establishes the need to preserve and improve the environment and refers to the spirit of solidarity among States members which must govern the Union's energy policy.

As a result, people have the right to enjoy an environment suitable for its development, as well as the duty to preserve it. The authorities "shall ensure the rational use of all natural resources, in order to protect and improve the quality of life and defend and restore the environment, relying on the indispensable collective solidarity” (art. 45.2 Spanish Constitution). The Spanish Constitution also determines, for those who do not use rationally all the natural resources and injured environment, criminal or appropriate sanctions, "as well as the obligation to repair the damage caused” (art. 45.3 Spanish Constitution). This right entails the sanctioning of public administrations and the obligation to repair the damage to the environment.

The specialization of the law has led also to a specialization of liability regimes. Civil and commercial standards of the old nineteenth-century codes are far that condensed into a few articles all forms of environmental tort liability (Esteve Pardo, 2008). Today there are increasingly more resortions to a larger number of texts. And these texts are more specific and more specialized material (Espí, 2015). The tangle of legal standards in each particular subject on pollution liability (i.e. Directive 2010/75/EU, Directive 
78/176/EEC; Directive 82/883/EEC; Directive 92/112/EEC; Directive 1999/13/EC; Directive 2000/76/EC of the European Parliament and of the Council; Directive 2001/80/EC of the European Parliament and of the Council; Directive 2008/1/EC...) determines an important problem of legal uncertainty.

Sometimes a regulatory concurrence of various environmental laws occurs, as it is the case with waste legislation and the legislation of environmental responsibility, which pursues the same purpose though the object of both regulations is based on different concepts (Varga Pastor, 2009), and that even to make doubt of what should be the standard to apply (Lata, 2016). Above all this overlaps another difficulty, very important: to articulate new standards with pre-existing liability regimes (Lozano Cutanda, 2009). This complexity is maintained even if the territorial scope of such "special" rules is sometimes supranational (as in the case of Community law directives) and even international (think of the international conventions on the protection of the natural environment).

Law 26/2007, about Spanish environmental liability, arose in this context (González Iglesias, 2015) as a comprehensive standard encouraging prevention and repair (Martín, 2010) of environmental damage and, incidentally, as a law regulating the liability arising from them. The object of the Law 26/2007 is to regulate the responsibility of the operators to prevent, avoid, and repair environmental damage according to the principles of prevention, "polluter pays". The scope of the law includes damage and imminent threats of damage to waters, to the banks of the estuaries and sea, soil and species of wild fauna and flora, as well as habitats. In addition, it applies only to the environmental damage that produces significant adverse effects on these resources, with the criteria established in the law. We can find requirements in the administrative and other possible liabilities (Martín, 2013; González Herández, 2012), as well as Directive 2004/35/EC of 21 April 2004 of origin, although it is far away the pretension of this Directive 2004, which cost so much effort to develop, to create a common regime of prevention and repair of damage to the environment in all Member States.

\section{Responsibility of the Administrators of the Society by the Environmental Responsibility of the Company}

In the 2007 environmental liability law to which we have referred there is a new and peculiar formula of responsibility of the managers of companies: environmental liability. Certainly in the last 25 years we have been attending in Spain phased and unstoppable escalation of the regime of civil liability of the managers of the Spanish capital companies, what has become a legal system like the Spanish—traditionally benevolent and lax-neglect or lack of interest of administrators in an extremely demanding legal network for these administrators of a polluting company.

However, despite this increased rigor (González, 2008), with this new responsibility-which is still a great unknown in Spain today-they were not at all. And it is that the 2007 environmental liability law holds personal responsiblility for administrators for the damage caused by the polluting managed company that they manage.

The origin of this precept is not an obligation to transpose Community legislation, since the Directive 2004/35/EC of the European Parliament and of the Council of 21 April 2004 on environmental liability with regard to the prevention and remedying of environmental damage, concerned exclusively the responsibility of the operators, without extending responsibilities to other subjects as administrators. The Spanish legislator, by surprise, without that nobody-neither the European Union nor international agreements-be it requested, again—as did earlier with the general regime of responsibility of administrators by not dissolution in the event 
of losses aggravated today in the Companies Act of Capital—adds on their own (Yanguas Montero \& Blázquez Alonso, 2008) an important plus of responsibility to the already very loaded suitcase of responsibilities of administrators.

This contribution of the legislature in 2007, which has been maintained until today, leads to several reflections. On the one hand, it is clear the intention of the legislator to incorporate a toughness and a great rigour in demand for responsibility of managers. And it is not a "passenger" rigor, or a result of an occurrence or an oversight to develop a specific law. The material scope of the liability of the precept remained and expanded later in other legal texts relating to environmental liability. Indeed, that initial article underwent an important ripple effect in other protective subsequent special legislation of the environment: the law 22/2011, July 28, of waste and contaminated soils, in article 36 refers to the subjects responsible for the decontamination and recovery of contaminated soils. And in this article refers to the regime of article 13 of the Law 26/2007, of October 23, environmental liability, which makes the administrators of these soils and residues responsible for polluting companies—solidary or subsidiary-managed society. This shows a clear interest of the Spanish legislator in the maintenance of this special responsibility of administrators before environmental damage and makes it clear that the intention of the legislator was to create and maintain a legal requirement line managers and that article 13 of the Law 26/2007 was not an isolated and lost in the midst of a legislative jungle standard, nor meant a slip of the legislator.

However, it is also true that more recently the legislator stops in demanding administrators of polluting companies in other environmental areas. Law 5/2013, of 11 June, by which the law 16/2002, of July 1 modified, integrated prevention and control of pollution and the law 22/2011, 28 July, waste and soil contaminated, which tends, as it outlines its preamble, to the application of the principle basic of any policy environmental is the prevention i.e. avoid pollution from the source before it is necessary to minimize its effects or to restore the affected resources, it is silent about this type of liability; it does not concern this form of liability of administrators of these polluting operators.

The environmental liability law distinguishes the following remedies: primary repair (any reparatory measure that replaces or approaching the maximum natural resources damaged the State in which they were before the damage - basic State); supplementary service (any restorative action taken to compensate for the fact that primary repair has not resulted in the full restoration of damaged natural resources); and compensatory repair (any action taken to compensate for interim losses of natural resources that occur from the date of the damage until the date on which the primary repair has all its effect occurred). Joining an instrument guarantees that the operator has sufficient resources to cope with environmental responsibilities. Financial guarantees (v. gr. insurance, technical reserve with certain requirements policy, endorsement) are compulsory for the activities of its annex III. However, in the case of these activities operators must confront all the obligations to prevent, avoid, and repair environmental damage that can be produced with its activity any case.

The legislator wishes to increase the number of possible subjects responsible for the harmful conduct of the environment (Campuzano Laguillo, 2009). And that adds to the range of directly responsible individuals that, by the performance of his office, are in charge of the management of the polluting company. You must call attention to the extension of responsibility managers in these cases of environmental pollution and not in other cases in which the company incurs liability for breach of other obligations and ethical conduct of the catalogue of corporate social responsibility. For example, it is not responsible for a "special" responsibility to administrators when they fail to comply with the duty to promote policies aimed at gender equality in the 
Council or the company hurts other consumers' interests.

When it comes to the responsibility of administrators, what are its characteristics and its limits? There is not a single form of liability of administrators of the contaminant entity, but different modes of liability.

The first requirement for triggering the joint and several liabilities of administrators is prior equity failure of polluting society according to the General tax law. Article 13 of the Law 26/2007 provides that they will be responsible for solidarity of the payment of pecuniary obligations arising from this law subjects to which refers to article 42.2 of the Act 58/2003, of December 17, General tax. That article 42 was drafted in 2006 among other standards for the prevention of tax fraud. It says that

...will also be responsible for solidarity of the payment of outstanding tax debt and, where appropriate, of the tax penalties, including the surcharge, and the interest on arrears for the period, when appropriate, up to the amount of the value of the property or rights that had failed to seize or dispose of by the tax administration, the following persons or entities: a) which are causing or collaborate in the concealment or transfer of goods or rights of the obligor to pay in order to prevent the performance of the tax administration; (b) where, by the fault or negligence, fail to comply with the orders of embargo; (c) which, with knowledge of the embargo, the injunction or the creation of the security, collaborate or consenting in the uprising seized rights or property, or those goods or rights on which it had set up as precautionary or security; (d) persons or depository entities of the assets of the debtor that, upon receipt of notice of the embargo, collaborate or the lifting of those consenting.

What interests most at the moment is the subsidiary responsibility of the duties collected in the Act, in particular the pecuniary obligations, which extends to other subjects (Gómez Ligüerre, 2011). It is provided for in the same article 13 of the environmental liability law and determines that subsidiarily responsible for environmental injury administrators who are administrators of right of the legal person, in fact of that person administrators, managers or administrators of legal persons that they have ceased their activities, the liquidators of legal persons (Miguel Perales, 2007) and insolvency administrators who have not done everything necessary to fulfill its duties and obligations in the delicate moments prior to the settlement or the Declaration of insolvency.

Article 13.2 of the environmental liability Act establishes ultimately a responsibility of subsidiarily applicable in certain cases on the administrators of the companies or bankruptcy administrators, who will operate when the company is not taking into account its obligations of prevention or repair and pecuniary obligations. Once the debtor of principal declared to fail and, where appropriate, supportive managers, administration shall issue Act of Declaration of liability, which shall be notified to the subsidiarily responsible for that answer for the obligations that they apply under environmental legislation.

It is arguable that the obligations included in this responsibility are all derived from the duties imposed by law 26/2007 or only the cash. When we speak of solidarity leaders, which refers to pecuniary obligations, as mentioned, but in the case of the subsidiary forced this nuance is not.

They will be subsidiary responsible administrators of fact and law for legal persons. Before the grammatical interpretation, logic and finalist in the precept we must admit the possibility of accumulation of subjective liability, i.e. the existence of a type of administrator doesn't exclude the responsibility of another type, if one exists, and will be responsible for all. These administrators will be responsible for at least all the pecuniary obligations arising from law 26/2007 coverage, sanctioning an objective and unlimited administrative responsibility for repair of the ecological damage determined by law.

They will also be responsible for subsidiaries of pecuniary obligations arising from law 26/2007 administrators 
of legal persons which would have ceased its activities, in any case and has been or not legal dissolution. They will be responsible for "in terms of the duties and obligations outstanding at the time of such termination", provided that they have not done enough to comply with agreements or taken measures cause of non-compliance.

And, finally, bankruptcy administrators, who had not made the necessary for the fulfilment of duties and obligations accrued before the Declaration of insolvency referred to in law 26/2007 shall also incur environmental subsidiary liability.

It should be noted that in cases of death or extinction of these administrators, individuals, or legal entities, the pecuniary obligations shall be transmitted in accordance with provisions for the tax obligations, so they will be transmitted to the heirs (Miguel Perales, 2007).

The law also foresees the causes of exclusion of liability to which the managers or the society may benefit (Sánchez, 2008), and allows repeating against the real culprits of the damage or threat to the environment. From the perspective of many corporate managers of operators responsible for environmental pollution, the current regulation introduces significant changes (in the preamble of the Act 12/2011 expression) in its own regime of responsibility, notably the extension of the period of claim for personal injury, which happens to be from 10 to 30 years. The importance of this responsibility is clearly evident from the expiration of the action: is given a comprehensive term for revocation of action, of thirty years, which should also be counted not from the date in which the harm originated, but from the date that harms ceased to occur.

\section{Conclusions and Policy Proposal}

It is still necessary to have environmental legislation and liability systems that effectively prevent environmental damage. Such systems of liability, in addition, must be extremely rigorous. Existing mechanisms to the present have shown, in terms of forecast of environmental responsibility, that they are inadequate, unsafe, and ineffective. We have been able to analyze briefly some features of a peculiar form of responsibility for the business managers prejudicial from the environment, which is applied in the Spanish subsidiary when the main operator does not fulfill its legal obligations in environmental matters. The Spanish law introduces a no doubt demanding responsibility, which exacerbated the already very rigorous regime of responsibility of the directors. The law introduces tries to ensure more attentive and scrupulous of all environmental obligations by those administrators who are in charge of the societies which may cause environmental damage. However, this is - when already 10 years have passed since its incorporation-a virtually unknown rule and has gone unnoticed among the abundant corporate and environmental legislation.

We can reflect on the desirability of introducing into national and international legislations-a forecast of subsidiary liability of the managers of enterprises of this type, and not only in the case of certain environmental damage, but to all cases of environmental responsibility. We believe that a regulation of this type would be interesting not to make easier or faster the repair, but for a much more interesting question: the prevention of environmental damage.

We totally agree with that "it is necessary to implement a principle of integration of the protection of the environment in all development measures and increase the degree of protection of geared towards guardianship pre-emption of the risks that could cause damage to the environment” (Oliveira Lanchotti, 2103).

At that point it would be interesting to introduce a precept as the one discussed here, which would force administrators of prejudicial environment entities to exercise their own diligence when it comes to implementation of the measures of care the company that administered. 
A personal and subsidiary responsibility of this kind would imply a radical change in the way of managing the society by their administrators, who no doubt would care in any case - even in case of delicate situation of the entity, which usually tends in practice to relax environmental measures, with the consequences we all know-in the environmental management of the company to not incur any personal liability for environmental damage. And this objective seems to be highly relevant. A new way is specified to manage that can mean a significant reduction of risks and, in consequence of damage to the environment.

Civil liability insurance covering those responsibilities of administrators, paid by the own companies and passed on to society in general with the price of goods and services, can relax in part the degree of extreme diligence with respect to these duties of administrators. Any case, an international precept which could introduce a forecast of subsidiary responsibility of the administrators of pollutant entities, would really guard this protected environment of the corporate social responsibility aspect currently very weak way, and could be a very important incentive to get maximum dedication and care in the protection of the environment by the managers of enterprises that are potentially harmful to the environment.

\section{References}

Baums, T., \& Scott, K. E. (2003). Taking shareholder protection seriously? Corporate governance in the United States and Germany. SLS, Working Paper, 272.

Bas, J. F. (2017). La responsabilidad medioambiental según el Derecho Comunitario. Economist \& Jurist.

Bernaldo De Quirós, I. (2005). “La responsabilidad social de la empresa”, La Gaceta de los Negocios, 10.

Brudney, V. (1982). The independent director : Heavenly city or Potemkin village? Harvard Law Review, 95(3), 597-659.

Buonocore, V. (2004). Etica degli affari e impresa etica. Giur. comm, I, 196-197.

Campuzano Laguillo, A. B. (2009). La responsabilidad de los administradores de las sociedades mercantiles (A. Rojo and E. Beltrán directores). Tirant lo Blanch, Valencia.

Caussain, J. J. (2004). Petit glosarie de la corporate governance. Derecho de Sociedades, 15-16.

Chulià, F. V. (1993). Problemas candentes de la Sociedad Anónima. Revista General de Derecho, 591, 11913.

Crook, G. (2005). The good company. The Economist.

Del Río, R. (2004). RSC: ¿Responsabilidad o marketing empresarial? Escritura Pública.

Espí, M. J. Z. (2015). La tutela jurídica del medio ambiente y los recursos naturales a través de la normativa española sobre responsabilidad medioambiental. Tesis Doctoral, Universidad Politécnica de Valencia, 95.

Esteve Pardo, J. E. (2008). Ley de responsabilidad medioambiental. Comentario sistemático, Marcial Pons, Madrid, 99-100.

Fernández García, R. (2016). Nueva perspectiva global en la estrategia medioambiental. Industria química, 41, 62-71.

Gómez Ligüerre, C. (2011). Pluralidad de responsables de un daño al medio ambiente. El artículo 11 de la Ley de responsabilidad medioambiental. Revista crítica de derecho inmobiliario, 723, 31-46.

González Herández, R (2012). La responsabilidad civil por daños al medio ambiente. Anuario jurídico y económico escurialense, $X L V, 190$.

González, J. Q. (2008). Responsabilidad medioambiental de los administradores concursales. Revista de Derecho Concursal y Paraconcursal, 649.

González Iglesias, M. A. (2015). Ley 11/2014, de 3 de julio, por la que se modifica la Ley 26/2007, de 23 de octubre, de Responsabilidad Medioambiental [BOE n 162, de 4-VII-2014], Ars Iuris Salmanticensis, 3, 188.

Hopt, K. J., \& Leyens, P. C. (2004). Board models in Europe-Recents developments of internal corporate governance structures in Germany, the United Kingdom, France, and Italy. Law Working Paper, 18.

Lata, N. Á. (2016). La obligación del propietario no contaminador de reparar los terrenos contaminados: La regulación del Derecho español a propósito de la Sentencia del TJUE de 4 de marzo de 2015. Revista General de Derecho Europeo, 39.

Lozano Cutanda, A. (2009). La responsabilidad medioambiental dos años después: ¿por qué se retrasa su aplicación? problemas y dudas sin resolver. Diario La Ley, 7270.

Martín, G. V. (2010). La responsabilidad medioambiental. Revista General de Derecho Administrativo, 25. 
Martín, G. V. (2013). Los últimos coletazos del viejo sistema español de responsabilidad por daños ambientales. Derecho PUCP, 71, 197-216.

Marín De La Bárcena, F. (2004). El concepto de interés social como fin de la actividad gestora en la proximidad a la insolvencia. Corporate Governance Conflicts And Corporate Insolvency, II Harvard-Complutense Seminar on Business Law, 13-15.

Miguel Perales, C. (2007). La nueva Ley de Responsabilidad Medioambiental: quedan cuestiones aún por resolver. Diario La Ley, 24, 6848-6849.

Miras Rodríguez, M. M., Carrasco Gallego, A., \& Escobar Pérez, B. (2014). Responsabilidad Social Corporativa y Rendimiento Financiero: un Meta-Análisis. Revista Española de Financiación y Contabilidad, 43(2), 193-215.

Oliveira Lanchotti, A. (2013). La evaluación de impacto ambiental en Brasil ante el reto de alcanzar un desarrollo sostenible. Tesis doctoral. http://hdl.handle.net/10578/3832

Orozco, C. (2015). Google Earth: el gran atlas del mundo cumple 10 años. Escritura Pública, 96, 43-44.

Salvadores, S. M. (2004). Solidaridad y ética empresarial. Escritura Pública, 27.

Sánchez, A. J. Q. (2008). Autorización administrativa y daño en el artículo 14.2 de la ley 26/2007, de responsabilidad medioambiental: ¿paso adelante o paso atrás? Diario La Ley, 7078.

Varga Pastor, A. (2009). La coordinación entre la Ley 10/1998 de residuos y la Ley 26/2007 de Responsabilidad medioambiental en materia de suelos contaminados. Revista Vasca de Administración Pública, 94, 241-255.

Visconti, R. M. (2004). Insolvenza d'impresa e conflitti di interesse tra stakeholders. Studi in memoria di Umberto Azzolina, a cura di Federico Bellini, Giuffrè Editore, Milán, 336-338.

Yanguas Montero, G., \& Blázquez Alonso, N. (2008). La nueva responsabilidad medioambiental. RDUMA, 245, $102-104$. 